\title{
Rhine loess at Schwalbenberg II - MIS 4 and 3
}

\author{
Wolfgang Schirmer
}

How to cite:

Schirmer, W. (2012): Rhine loess at Schwalbenberg II - MIS 4 and 3. - E\&G Quaternary Science Journal, 61 (1): 32-47. DOI: 10.3285/eg.61.1.03

Abstract:

The locality Schwalbenberg is situated in the Middle Rhine valley close to the town of Remagen. It exhibits a rather complete section of the Last Glacial loess with good tripartite subdivision of the Lower Pleniglacial (Keldach Formation, MIS 4) with one interstadial soil, excellent subdivision of the Middle Pleniglacial (Ahrgau Formation, MIS 3) with eight interstadial soils, and minor subdivision of the Upper Pleniglacial (Hesbaye and Brabant Formation). A first profile log, Schwalbenberg I, published earlier with organic carbon (Corg) and phosphorus curves, showed that the Middle Pleniglacial Schwalbenberg section represents an excellent mirror image of MIS 3 curves of ice and deep sea cores. This text presents a new profile $\log$ from a new wall, Schwalbenberg II, with tighter sampling ( $6 \mathrm{~cm}$ per sample). Grain-size and carbonate curves show the tripartition of smaller coarse silt content and carbonate content in the Keldach Formation, fluctuating coarse silt and carbonate in the Ahrgau Formation and enhanced coarse silt and carbonate in the Upper Pleniglacial. The nine interstadial soils (calcaric cambisols and one calcaric regosol) turn out to be autochthonous due to maxima of organic carbon, minima of carbonate and pedogenic top down intrasol zonation. All gelic gleysols show carbonate maxima. The Corg curve of Schwalbenberg II and $\delta^{18} \mathrm{O}$ record of the annuallayer counted Greenland GISP 2 core show strikingly good correlation of rhythmicity and magnitude between the Ahrgau Formation and the Greenland interstadials 17 to 5 . This correlation is widely confirmed by numerical dating of the Schwalbenberg II section. The boundary Ahrgau Formation/Hesbaye Formation (MIS 3/MIS 2) was drawn so far with the top of the uppermost cambisol (Sinzig 3 Soil). Lithological and chronological data speak for drawing the boundary somewhat higher at the Hesbaye Discordance. Consequently, the Schwalbenberg section misses the soil representing the GIS 5 interstadial. Nevertheless, it presents the most complete Ahrgau Formation (MIS 3) in western Europe. Loess profiles of the more continental region in the northeastern Carpathians or in Siberia are even richer in soils.

\section{Rheinlöss von Schwalbenberg II - MIS 4 und 3}

Kurzfassung:

Die Lokalität Schwalbenberg bei Remagen am Mittelrhein erschließt ein sehr vollständiges Profil durch den letztglazialen Löss mit drei Großgliedern. Gut gegliedert sind der Löss der Keldach-Formation (Früh-Weichsel/Würm-Hochglazial, MIS 4) mit einem Interstadial-Boden und der Löss der Ahrgau-Formation (Mittelweichsel/-Würm-Interstadial-Komplex, MIS 3) mit acht Interstadial-Böden. Den Abschluss nach oben bildet weniger gut gliederbarer Löss des Jung-Weichsel/Würm-Hochglazials. Zu bereits veröffentlichten organischen Kohlenstoff (Corg)- und Phosphor-Kurven einer ersten Profilaufnahme, Schwalbenberg I, präsentiert dieser Text Daten des Profils Schwalbenberg II: AMS ${ }^{14} \mathrm{C}$-Datierungen, Korngrößen, Corg- und Karbonatgehalt. Die Korngrößen spiegeln die Dreigliederung wider mit Grobsilt-ärmerem Keldach-Löss, schwankendem Siltgehalt im Ahrgau-Löss und Grobsilt-reicherem Jungwürmlöss. Auch im Karbonatgehalt spiegelt sie sich mit Karbonat-ärmerem Keldach-Löss, schwankenden Gehalten im Ahrgau-Löss und Karbonat-reicherem Jungwürmlöss. Die neun interstadialen Böden erweisen sich durch Corg-Gipfel und Karbonat-Minima vereinigt mit pedogener Zonierung bodenintern von oben nach unten als autochthone Böden. Alle Nassböden zeigen Karbonatmaxima. Der Vergleich der Corg-Kurve mit der der $\delta^{18} \mathrm{O}-\mathrm{Kurve}$ des jahrring-zonierten grönländischen Eiskerns GISP 2 zeigt für die Ahrgau-Formation - wie früher schon die Kurven vom Schwalbenberg I - erneut nach Kurvenrhythmik und Magnitude hohe Gleichläufigkeit des Klimaverlaufes zu den Grönland-Interstadialen 17 bis 5. Nummerische Daten vom Schwalbenberg II unterstützen das weitgehend.

Zur Frage, ob die Grenze Mittel-/Oberwürm (MIS 3/MIS 2) nach dem obersten braunen Boden (Sinzig 3-Boden) oder wenig höher mit der Hesbaye-Diskordanz zu ziehen ist, sprechen die meisten lithologischen und die chronologischen Kriterien für die Grenzziehung an der Hesbaye-Diskordanz. Ansonsten ist der Schwalbenberg unter den gut vergleichbaren Lössprofilen im westlichen Europa bisher das am detailliertesten gegliederte MIS 3-Profil. Reicher gegliedert sind nur Lössprofile des kontinentaler geprägten Raumes in der nordöstlichen Karpatenregion und in Sibirien.

Keywords: $\quad$ loess stratigraphy, grain size, TOC, carbonate

Address of author: $\quad$ W. Schirmer, Department of Geology, Heinrich Heine University Düsseldorf. Mailing address: 91320 Wolkenstein 24, Germany. E-Mail: schirmer@uni-duesseldorf.de

\section{Introduction}

Up to now the Schwalbenberg section exposed the most detailed loess stratigraphy of MIS 3 (Middle Würmian/ Weichselian) in western Central Europe by a multiplicity of intercalated fossil soils. In 1989 the $13 \mathrm{~m}$ high loess section of the Schwalbenberg close to Remagen/Middle Rhine (Fig. 1) was sampled continuously by 99 samples later called section Schwalbenberg I. (Continuous sampling means that the whole section - of here $13 \mathrm{~m}$ - is sampled from base to top without any gap betwen the single samples.) When Schwalbenberg I was analyzed, the enormous significance of the section became visible - a true mirror image of the Greenland ice curves during MIS 3 (SCHIRMER 1990a, 1991).

This gave rise to tighter sampling of this $13 \mathrm{~m}$ high loess section. When in 1991 the Schwalbenberg loess wall was 


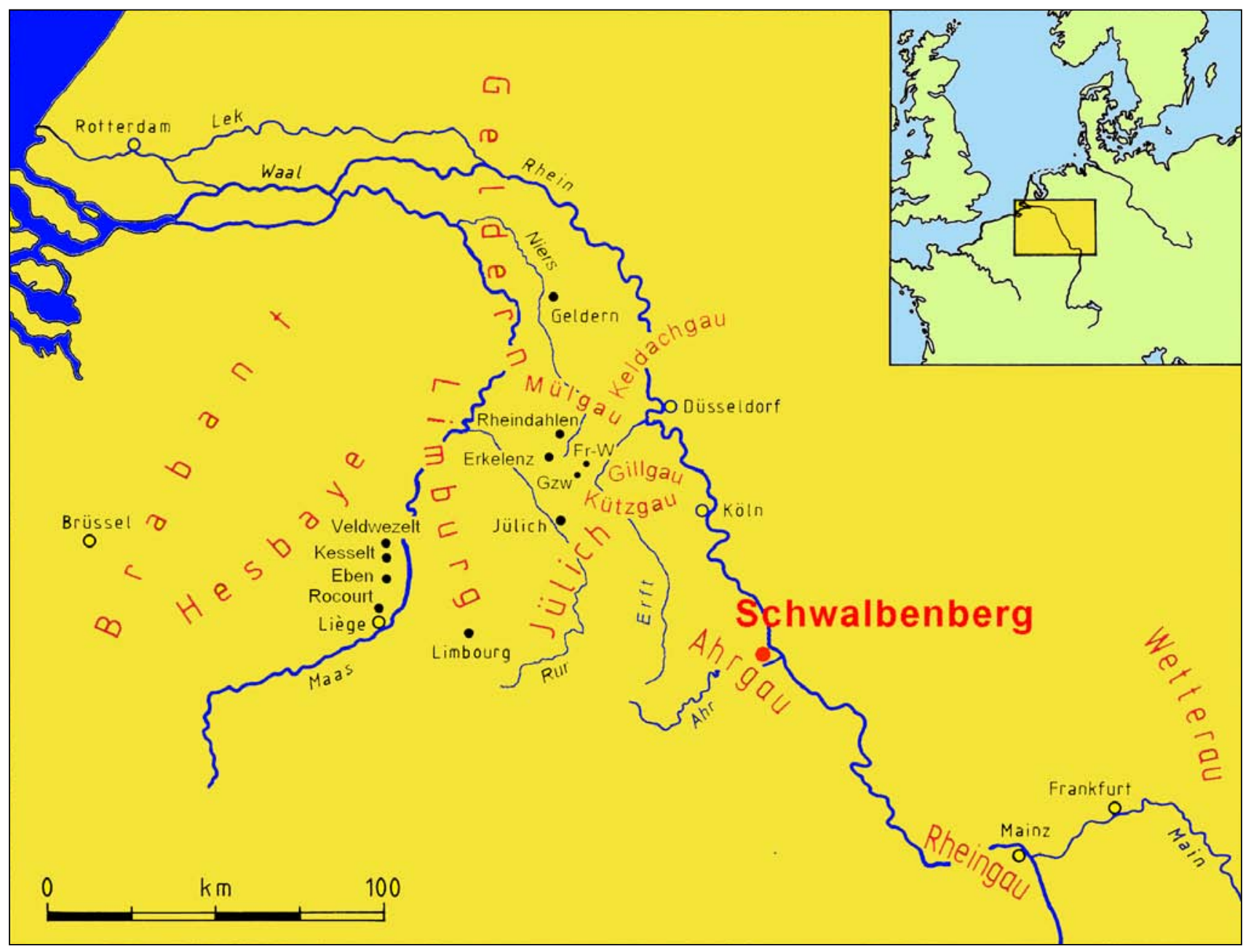

Fig. 1: Loess localities (black dots) at the Middle and Lower Rhine with the location of the Schwalbenberg section (Fr-W=Frimmersdorf-West, Gzw $=$ Garzweiler).

Abb. 1: Löss-Lokalitäten (schwarze Punkte) am Mittel- und Niederrhein mit Lage des Schwalbenberg-Profils (Fr-W=Frimmersdorf-West, Gzw = Garzweiler).

exploited several meters backwards to enlarge a garden I took a new profile log with 216 continuous samples called Schwalbenberg II (Fig. 2). Thus, Schwalbenberg II is a newly logged section on a new wall some meters behind the wall of Schwalbenberg I.

This paper presents first proxy data of the Schwalbenberg II section in order to specify the proxy data for their comparison with other detailed MIS 3 records.

\section{Location}

The Schwalbenberg locality (R 258824, H 560356, $92 \mathrm{~m}$ a.s.l) is situated within the Middle Rhine reach. Here, the Rhine pierces the Rhenish Shield (Rheinisches Schiefergebirge). As this shield has been rising especially since Pliocene, the Rhine had to cut in, forming a terrace staircase with the famous romantic Rhine gorge.

The Schwalbenberg lies on the western slope of this narrow entrenched valley at the northern corner of the mouth of a left tributary, the Ahr River (Fig. 1). The base of the loess profile lies $28 \mathrm{~m}$ above the Rhine river level on top of an eroded river terrace, the Lower Middle Terrace (Untere Mittelterrasse) that is attributed to the penultimate glaciation (SCHIRMER 1990a). The cliff embracing the gravel of the Lower Middle Terrace with the loess section on top joins a $2 \mathrm{~km}$ wide flat plain, the so called Goldene Meile. This terrace plain represents the late Weichselian Low Terraces (Niederterrassen) and Holocene floodplain terraces at the junction of the rivers Rhine and Ahr (SchIRmer 1990b). As the steep loess outcrop is part of a private garden, we had to plant the ledges of the cliff wall after the investigations; meanwhile the cliff is overgrown.

\section{The Schwalbenberg II section - its litho-pedological composition and age}

\subsection{The Schwalbenberg II section and its stratigraphical frame}

The profile Schwalbenberg II is drawn in Fig. 2 showing the exact position of samples 1-216 and the rough stratigraphic interpretation of the section that is explained in the sequel. The profile log is given in Tab. 1. A rough subdivision starts with a Bt horizon topping the basal gravel. It is regarded as the last interglacial soil that normally tops the Lower Middle Terrace (Schirmer 1990a). This soil is unconformably cut by the Keldach Discordance and overlain by a $13 \mathrm{~m}$ thick loess-soil sequence piling up to the recent surface. The loess-soil sequence is tripartite by a $3.2 \mathrm{~m}$ lower loess, preferably solifluidal, a some $7 \mathrm{~m}$ thick middle loess with 


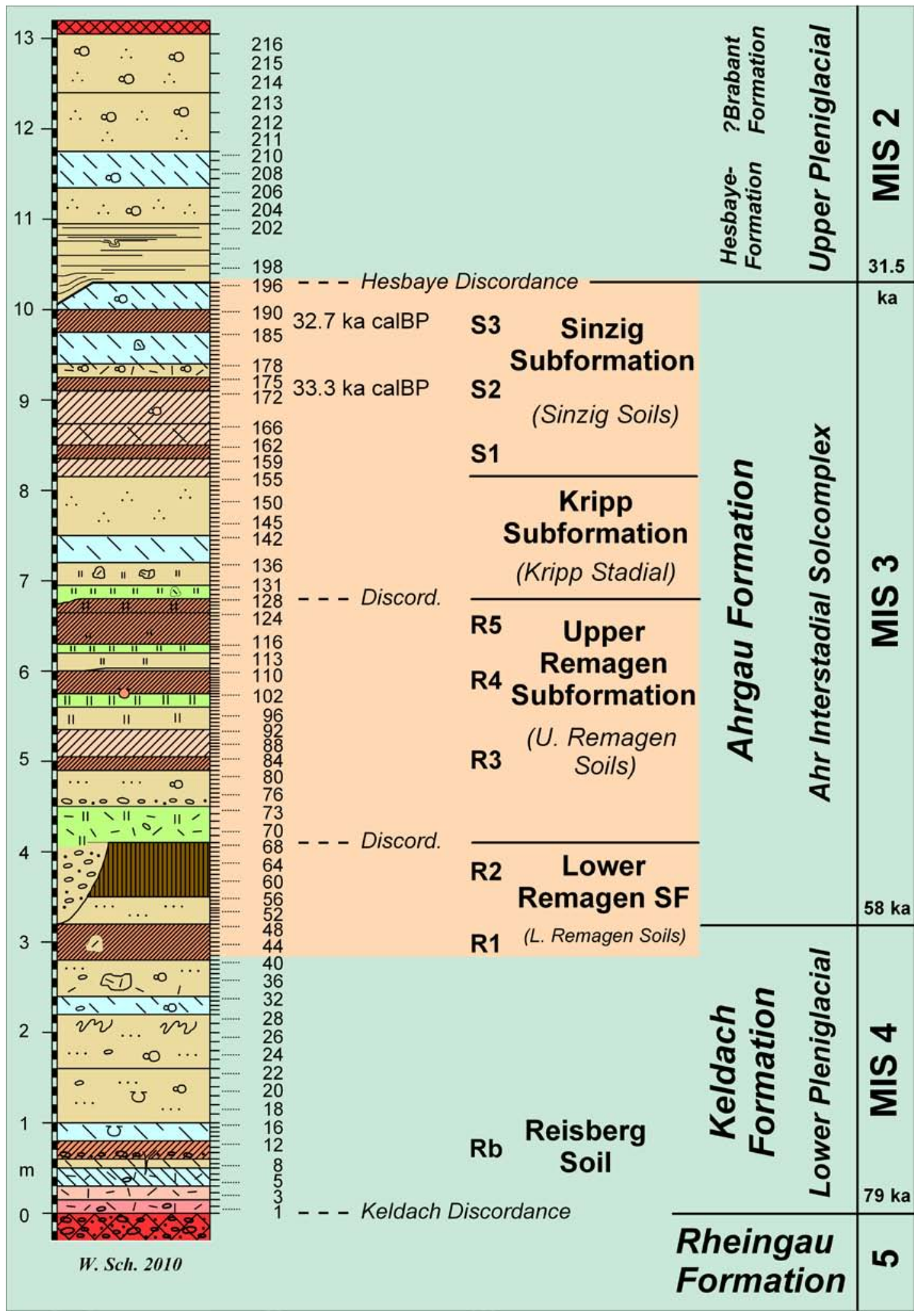

Legend

eolian loess

solifluidal loess/ laminated loess, colluvial loess

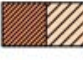

Ah humus

Grey Gelic Gleysol

pseudogley: bleached vertical streaks bounded by rust seams

$\begin{array}{lll}\text { By } & \text { luvisol: } \\ \text { Bt horizon }\end{array}$

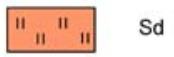

Speckled Gelic

Gleysol

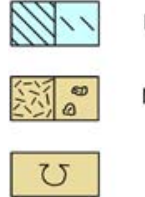

reworked

soil sediment

crotovina

grave

Fig. 2: Profile Schwalbenberg II with samples 1-216 and the stratigraphic interpretation of the section. The brown field marks the stretch of the MIS 3 interstadial soil formation. Its basal extension down into MIS 4 is due to the fact that the substratum of the R1 Soil belongs to MIS 4, whereas the soil formation correlates to MIS 3. SF = Subformation; ka after Greenland ice cores.

Abb. 2: Profil Schwalbenberg II mit den Proben 1-216 und stratigraphischer Interpretation. Das braune Feld kennzeichnet den Bereich der interstadialen Bodenbildung im MIS 3. Sein Übergreifen auf MIS 4 geschieht dadurch, dass das Substrat des R1-Bodens wohl MIS 4-zeitlich, die Bodenbildung aber MIS 3-zeitlich ist. SF = Subformation; ka gemäß Grönland-Eiskernen. 
an eight-fold soil complex of mostly calcaric cambisols, and a scanty $3 \mathrm{~m}$ upper loess, preferably eolian loess.

The Lower Pleniglacial loess, the Keldach Formation, starts with the Keldach Discordance. The Keldach Discordance at the base of the Weichselian Lower Pleniglacial is a widespread phenomenon in central Europe cutting at many places the Rheingau Formation (MIS 5) with its Rocourt Solcomplex (ScHIRMER 2003: 49). The above following $3.2 \mathrm{~m}$ thick loess layer is correlated litho-pedo-stratigraphically with the Weichselian Lower Pleniglacial for the following reasons:

It is the widely distributed early loess between the Rocourt Solcomplex (MIS 5) and the soil complex of the Ahrgau Formation (MIS 3). The loess facies of this lower loess is throughout solifluidal loess, which is typical for the Keldach Formation (MIS 4) in whole central Europe. At its base occurs more or less reworked red or brown soil sediment, present here between profile meter $0-0.5$; it is reworked soil material from the partly eroded Rheingau Formation that normally embraces four Bt horizons (SCHIRMER 2000a, b). The weak Reisberg cambisol fits well to two weak soils, the Jackerath and Spenrath Soil, which occur in the lower part of the Keldach Formation in the Lower Rhine basin (Schirmer 2002a: 19). Below and above the Reisberg Soil occur Grey Gelic Gleysols that likewise are typical for the Keldach Formation.

Thus, from facies, soils and its litho-pedo-stratigraphical position this basal loess unit is a typical representative of the Lower Pleniglacial (MIS 4). Nevertheless, bracketed by the Rocourt Solcomplex below and the Middle Pleniglacial brown soil cluster above, this thick loess unit would neither fit to the Rheingau Formation with its Bt horizon and humus zones nor to the Ahrgau Formation with its brown soils and mostly Speckled Gelic Gleysols.

The following Ahrgau Formation represents the typical brown soil bundle of the Middle Pleniglacial. This tight soil-loess sequence shows three soil groups, two Lower Remagen Soils, three Upper Remagen Soils and three Sinzig Soils. Each soil group is capped by a discordance and separated from the next group by a somewhat thicker loess layer. These two discordances at profile meter 4.1 and 6.8 effect incomplete soil sequences in several positions of the wall that make the investigation of the sheer cliff not easy (Fig. 3). The brown cambisols of the Ahrgau Formation are interbedding with gelic gleysols of two types, the rusty and grey Speckled Gleysol in the lower part and the homogeneously Grey Gelic Gleysol in the upper part.

In earlier publications it was shown that the eight-fold solcomplex of the Ahrgau Formation matches phenologically in details with MIS 3 in the Grand Pile section (Vosges), in ice cores (Dye 3, Camp Century, GRIP Summit) and deep-sea cores (DSDP-609, KET 8004). Therein it correlates to the Greenland interstadials GIS 17 to 6 thus forming an own interstadial complex, the Ahr interstadial complex, which is interbedded between the Weichselian Lower Pleniglacial loess and the Upper Pleniglacial loess (Schirmer 1995a: 513, 1995b: 531, 1999, 2000a, b, 2002a: 11, 19, 2002b: 318-319, 2004).

The upper boundary of the Ahrgau Formation, either drawn with the top-line of the uppermost brown soil, the Sinzig 3 Soil, or at the Hesbaye Discordance, is discussed below.

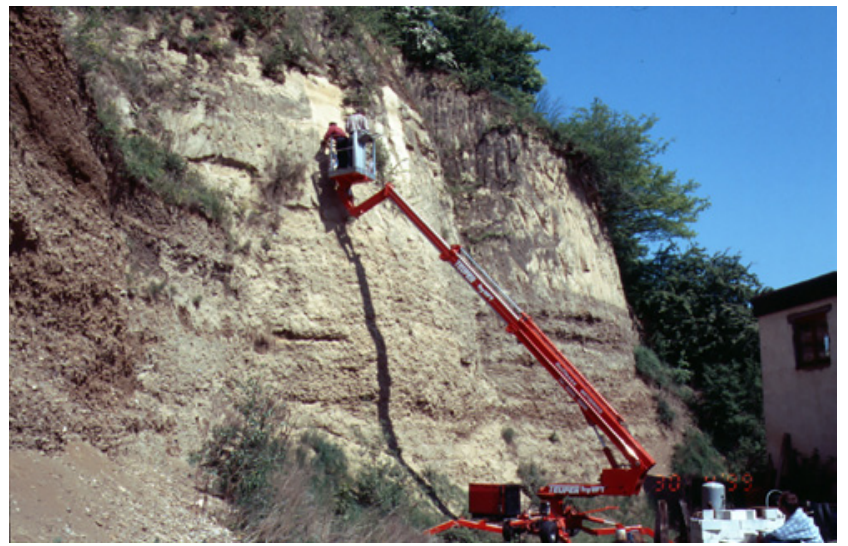

Fig. 3: Cliff of the Schwalbenberg II section. Gravel of the Lower Middle Terrace covered by a loess-soil sequence. Sampling by a mobile elevation work platform (cherry picker). Photo: W. Schirmer 30.04.1999.

Abb. 3: Kliff des Schwalbenberg II-Profils. Unten Schotter der Unteren Mit telterrasse, darüber Löss-Boden-Folge. Beprobung mit Hilfe einer Hubarbeitsbühne. Foto: W. Schirmer 30.04.1999.

The Upper Pleniglacial loess contains laminated colluvial loess in its lower part, eolian loess above it with one Grey Gelic Gleysol intercalated. The little subdivision of this $3 \mathrm{~m}$ thick loess unit does not allow its distribution to the Hesbaye and Brabant Formations.

\subsection{Datings from the Schwalbenberg II section}

The litho-pedologic association of the Ahr Interstadial Solcomplex with MIS 3 is supported by the following chronological data:

In a neighboring section, some decades of meters nearby, a prehistoric excavation revealed a smaller soil sequence of cambisols. The uppermost soil of them was dated by ${ }^{14} \mathrm{C}$ of mollusks to $32,669 \pm 521$ a calBP CalPal $\left({ }^{14} \mathrm{C}: 28,100 \pm 530\right.$ a BP, Pta-2721) and $32,487 \pm 430$ a cal BP CalPal $\left({ }^{14} \mathrm{C}: 27,900 \pm 440\right.$ a BP, Pta-2722, both dates App et al. 1995: 29) and by TL to $31.3 \pm 2.6$ ka (ZöLler et al. 1991: 409). A gelic gleysol quite above the cambisol had a TL age of 29.6 $\pm 2.7 \mathrm{ka}$ (ZöLLER et al. 1991: 409). The dated cambisol might match with the Sinzig 3 Soil of Schwalbenberg II; but it is not fully proved due to the shortdistance changes of the strata sequence at the steep cliff and behind it. Therefore these data are not included in Fig. 2.

In the Schwalbenberg section II an AMS age from gastropods Pupilla sterri of the Sinzig 3 Soil yielded 32,653 \pm 377 a calBP CalPal $\left(28,200+300 /-290{ }^{14} \mathrm{C}\right.$ a BP, KIA22209), and from the same gastropod species of the Sinzig 2 Soil $33,347 \pm 429$ a calBP CalPal $\left(28,860+300 /-290{ }^{14} \mathrm{C}\right.$ a BP, KIA22208). The agreement between the mollusk data of the Sinzig 3 Soil and that of the above mentioned section makes a correlation of both soils probable.

In the Schwalbenberg II section itself a set of 27 IRSL and TL datings gave ages of the Ahr Solcomplex between 45 and 25 ka (FRECHEN \& SCHIRMER 2011: 85f.).

Cofflet (2005) finds a possible hint for the presence of the Laschamp Event by a relative low palaeointensity within the stretch of the Remagen 3-5 Soils and the following Kripp Stadial, resp. the stretch around GIS 12 to GIS 9.

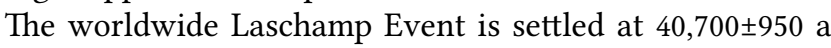
before 2000 AD within GIS 10 (SINGER et al. 2009). 


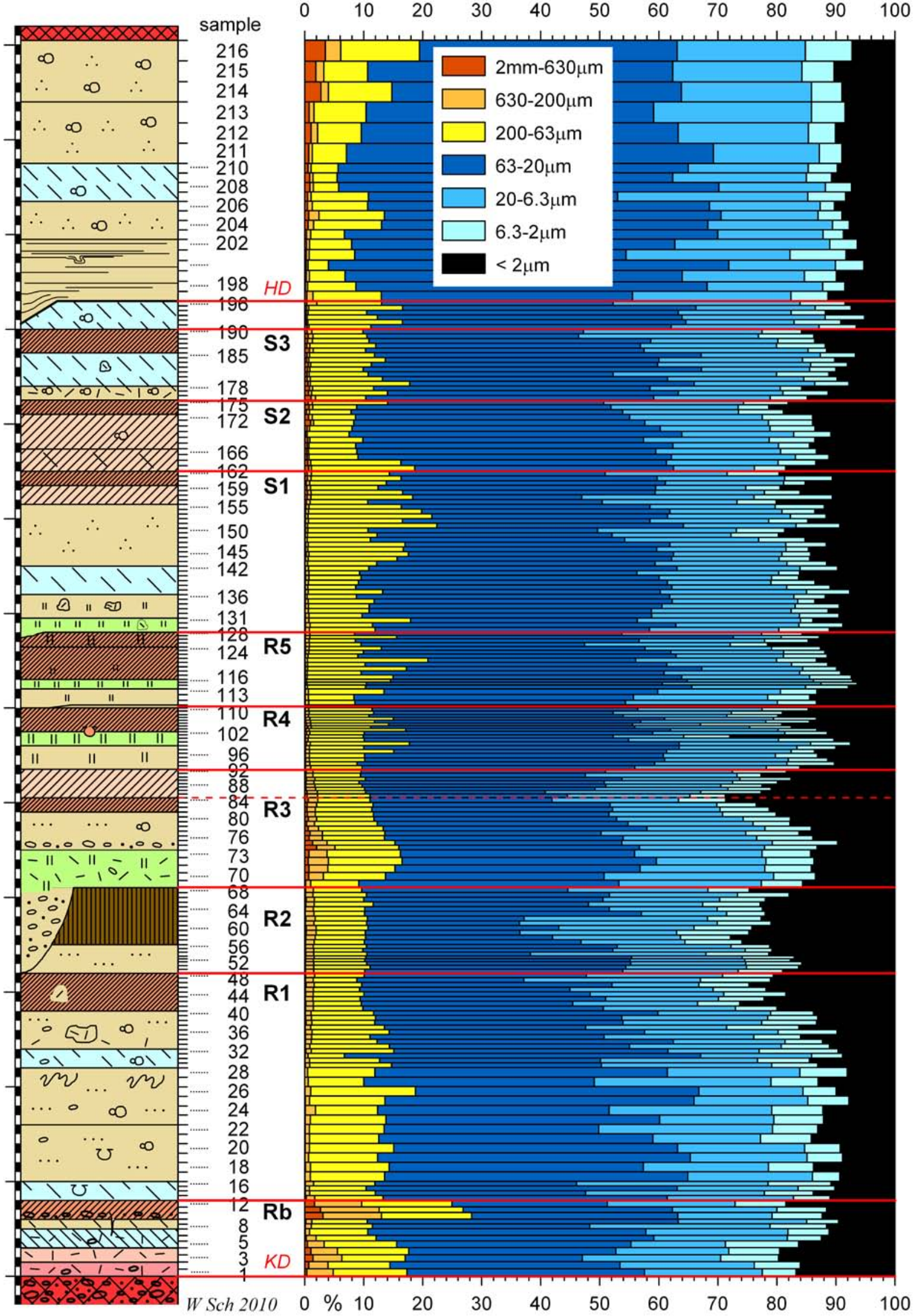

Fig. 4 Schwalbenberg II section with seven grain size fractions: $100 \%$ diagram. Red lines mark soil tops, the Hesbaye (HD) and Keldach Discordance (KD). Profile legend see Fig. 2.

Abb. 4 Profil Schwalbenberg II mit sieben Korngrößenfraktionen: 100\%-Diagramm. Rote Linien kennzeichnen Bodenoberflächen und die Hesbaye- (HD) und Keldach-Diskordanz (KD), Profillegende in Abb. 2. 

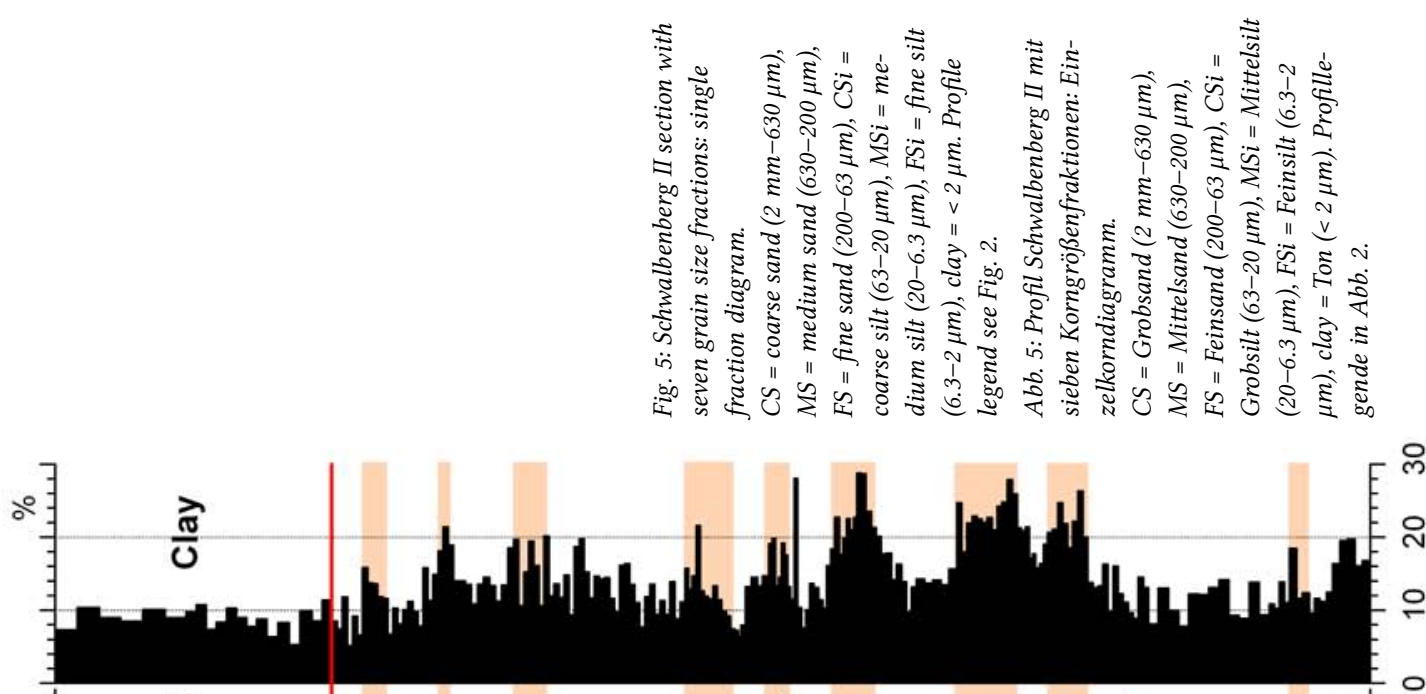

-
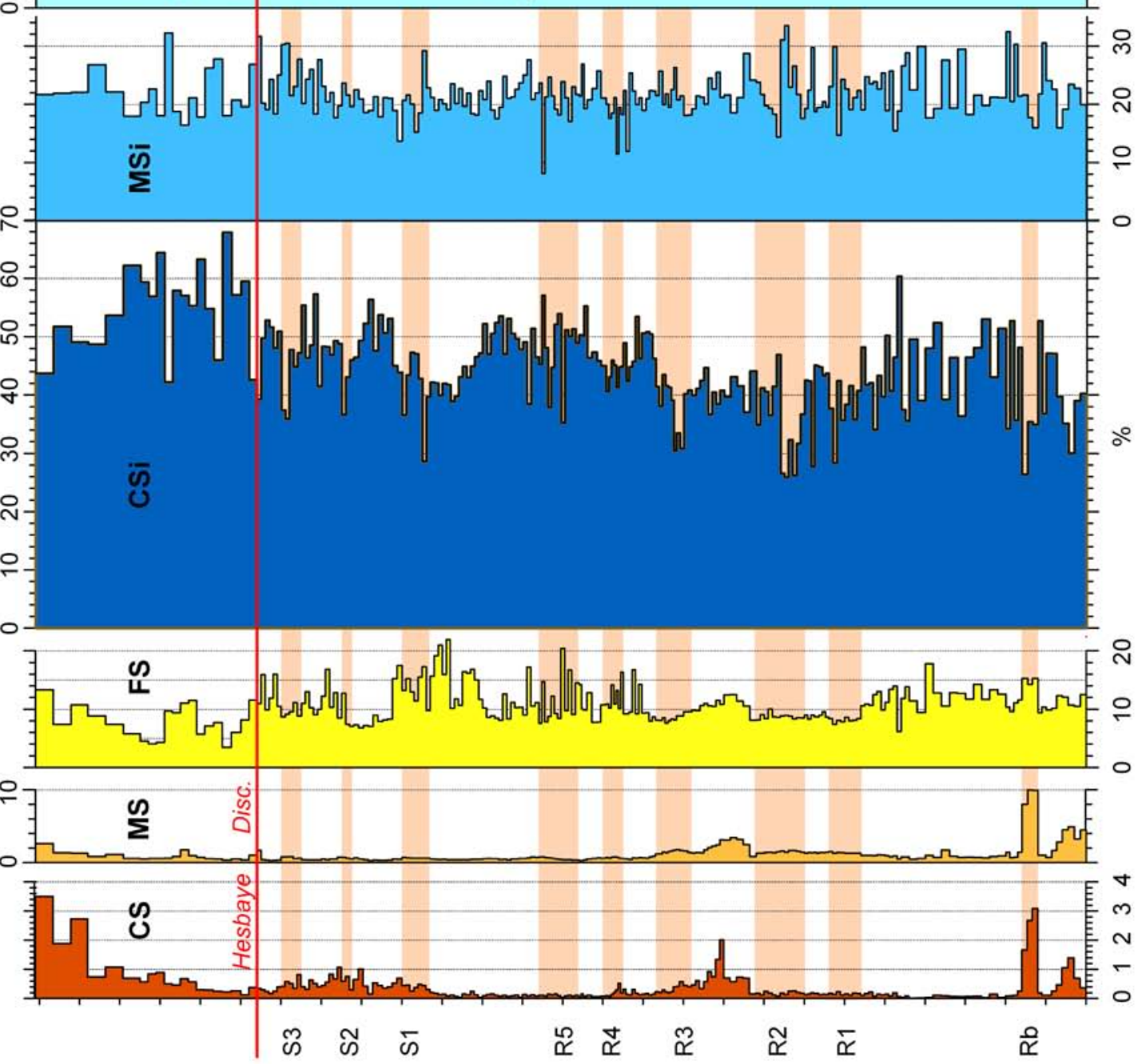

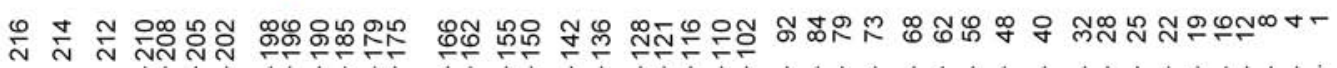

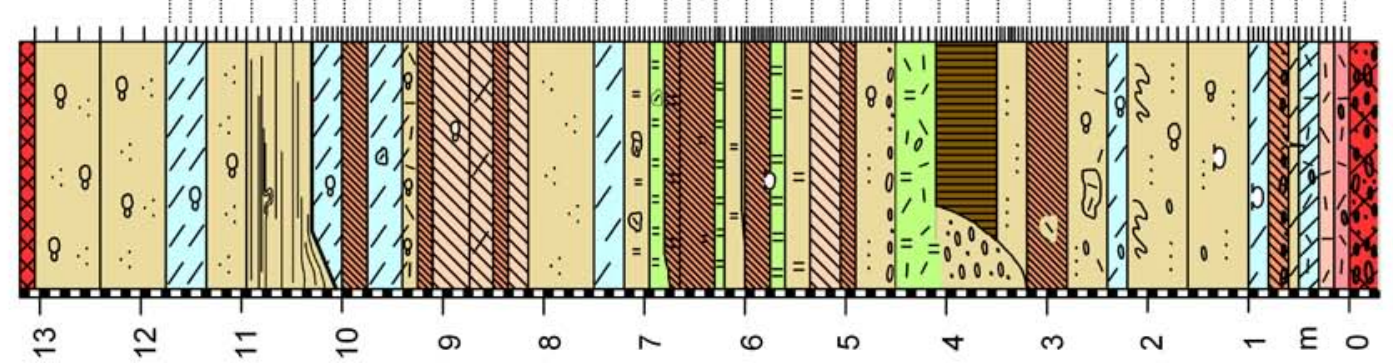


All datings confirm the phenological correlation of the Schwalbenberg section with long records from ice and deep sea.

The Keldach Formation within the Schwalbenberg II section was covered by 12 IRSL and TL datings, which gave ages between 55-45 ka (Frechen $\approx$ Schirmer 2011). These ages contradict the assignment of the Keldach Formation to MIS 4 (see discussion in chapter 5).

\section{Schwalbenberg II proxy-data and their discussion}

The sampling of the Schwalbenberg II section was continuously, within the Ahrgau Formation (MIS 3) in vertical columns of $5 \mathrm{~cm}$, sometimes even $3 \mathrm{~cm}$, above and below the Ahrgau Formation mostly $10 \mathrm{~cm}$. The heights of the sampled columns are depicted in Figs. 2 and 4-7. By sampling in vertical columns the analyse values represent the whole vertical stretch of one sampled column. Continuously sampled columns avoid gaps within the whole sedimentary record of the section.

This chapter presents the grain size analysis, organic carbon and carbonate content of the Schwalbenberg II. Paleomagnetic data are given in the PhD work of COFFLET (2005), first mollusk analyses in SCHIERMEYER (2000).

\subsection{Grain size analysis}

From clastic sediment $<2 \mathrm{~mm} \varnothing$ seven grain size fractions were measured: coarse sand $2 \mathrm{~mm}-630 \mu \mathrm{m}$, medium sand 630-200 $\mu \mathrm{m}$, fine sand $200-63 \mu \mathrm{m}$, coarse silt $63-20 \mu \mathrm{m}$, medium silt $20-6.3 \mu \mathrm{m}$, fine silt $6.3-2 \mu \mathrm{m}$ and clay $<2 \mu \mathrm{m}$. The whole sample was fractioned by gravity sedimentation using a fully automatic apparatus after WERNER (1973) that is pipetting the silt and clay. Subsequently the sand was wet-sieved. Pretreatment: $15.0 \mathrm{~g}$ of non-decalcified clastic sediment pre-dried with $80^{\circ} \mathrm{C}$ was peptized by $\mathrm{Na}_{4} \mathrm{P}_{2} \mathrm{O}_{7}{ }^{*} 10$ $\mathrm{H}_{2} \mathrm{O}$ and vibromixed for $12 \mathrm{~min}$.

The nine calcic cambisols resp. the regosol are each marked by clay peaks (Figs. 4 and 5). The maximum clay concentration lies within the Remagen 1-3 Soils. The clay peaks are descending from R3 to R5, which is important for the comparison with the Greenland interstadials. The Sinzig Soils show less clay formation, similar to R4-5. Among the Sinzig Soils the S2 shows the maximum clay peak as well as the maximum average clay volume.

Similar to the clay, the fine silt shows slight tendency towards increase in the soils. The medium silt is indifferent. Coarse silt retreats in the soils. It rises distinctly above the Ahrgau Formation. Fine sand retreats during the clay augmentation phases in R1-R3 and during coarse silt progression above the Ahrgau Formation.

Maxima of coarse, medium and fine sand at the base of the section between 0 and $1 \mathrm{~m}$ and between R2 and R3 Soils indicate enhanced sediment shift, obvious in the substratum of the Reisberg Soil, which is a solifluidal loam.

\subsection{Organic carbon [Corg]}

The organic Carbon content (TOC) was analysed with a Dimatec laboratory furnace by combustion at $480^{\circ}$. Pretreatment: The sediment $<2 \mathrm{~mm} \varnothing$ was pulverized and dried with $80^{\circ} \mathrm{C}$ for 24 hours, again pulverized and dried with $105^{\circ}$ for 2 hours.

The red Corg curve in Fig. 6 is a mean curve showing the arithmetic mean of the various analyses made from one sample. The curve shows 216 values from 459 single analyses.

All terrestrial soils are marked by maxima in Corg. Soil Remagen 3 (R3) shows the highest peak with about $0.5 \%$ Corg. The Upper Remagen Soils (R3-R5) show a descending peak sequence from older to younger soils, respectively from R3, the highest peak of the whole Ahrgau Formation, to R5, the lowest peak of this sequence. Likewise the Sinzig Soils (S1-S3) exhibit a descending peak sequence from older to younger soils, respectively from S1, the highest peak, to S3, the lowest peak. Additional Corg peaks occur in sample 2-6 presenting solifluidally reworked soil material (M), and in sample 197 presenting colluvial loess and a possible hint for an eroded soil (see chapter 5).

The Corg levels of the Lower Pleniglacial and the Upper Pleniglacial loesses below and above the Ahrgau Formation are roughly the same. The Corg values of the cold periods in-between the Ahrgau soils exhibit a little bit higher values than the pleniglacial loesses.

\subsection{Carbonate content}

The sample $<2 \mathrm{~mm} \varnothing$ was analyzed with a Dimatec laboratory furnace by combustion at $1000^{\circ}$ (TC). The carbonate content was calculated by subtraction of the combustion value at $400^{\circ}$ (TC-TOC) and converting the $\mathrm{C}$ value to $\mathrm{CaCO}_{3}$. Pretreatment: The sediment $<2 \mathrm{~mm} \varnothing$ was pulverized and dried with $80^{\circ} \mathrm{C}$ for 24 hours, again pulverized and dried with $105^{\circ}$ for 2 hours.

All calcaric cambisols and the regosol (brown bands behind the curve of Fig. 7) show minima of the carbonate content. In some cases the minimum lies in the soil top: Reisberg Soil (Rb), Remagen 1 Soil (R1) and Sinzig Soils S1 and $\mathrm{S} 2$. This indicates decalcification starting from the surface of the soils - perfect curves to give prove of the autochthony of the soils. Other cases show the minimum in the midst of the soils or somewhat below: soils R2-5. This points to a secondary carbonate infiltration from above. Moreover, decalcification of the soils causes maxima of the carbonate content at the soil base or below (downward lime illuviation), visible with R1 and R2. The maxima below the other cambisols coincide with gelic gleysols.

All in all, during soil formation all cambisols and the regosol underwent a certain decalcification process. In addition, all of them received a subsequent secondary carbonate infiltration from above. Whether they ever were completely decalcified remains unknown.

All gelic gleysols (the grey type as well as the speckled type) show maxima of the carbonate content. Peaks towards $30 \%$ occur in the gelic gleysols at samples no. 7, 112 and 140. The gelic gleysols represent thawing horizons on top of the permafrost with water stagnation. It is interesting that the terrestrial soils, cambisols and the regosol, always are topped by gelic gleysols, whether Grey or Speckled Gelic Gleysols. Hence, the cambisols work as aquicludes.

Average carbonate content of the whole Schwalbenberg section is $18.3 \%$. Among the three subunits, Keldach loess, 


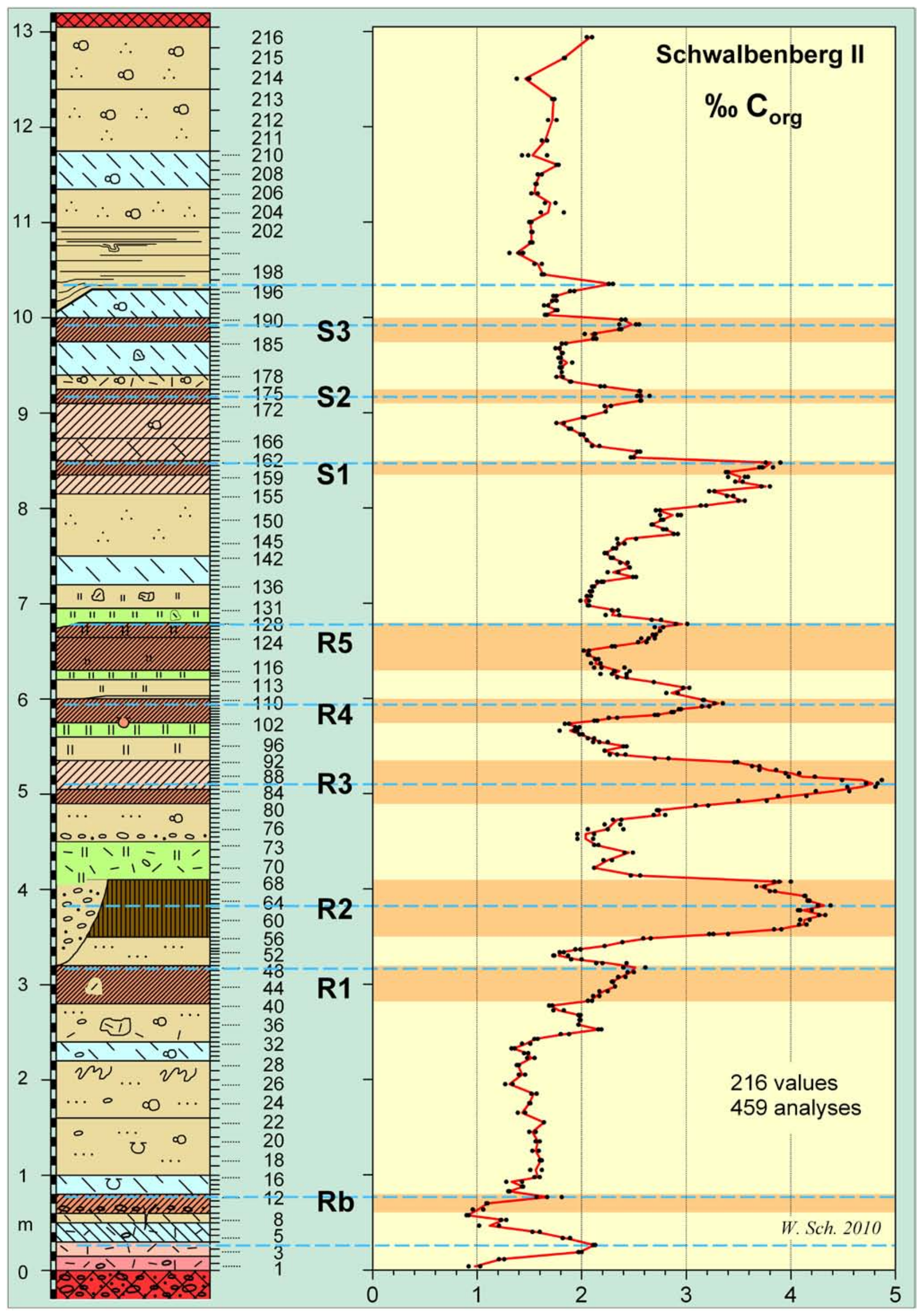

Fig. 6: Schwalbenberg II section with curve of the organic carbon. Profile legend see Fig. 2.

Abb. 6: Profil Schwalbenberg II mit Kurve des organischen Kohlenstoffs. Profillegende in Abb. 2. 


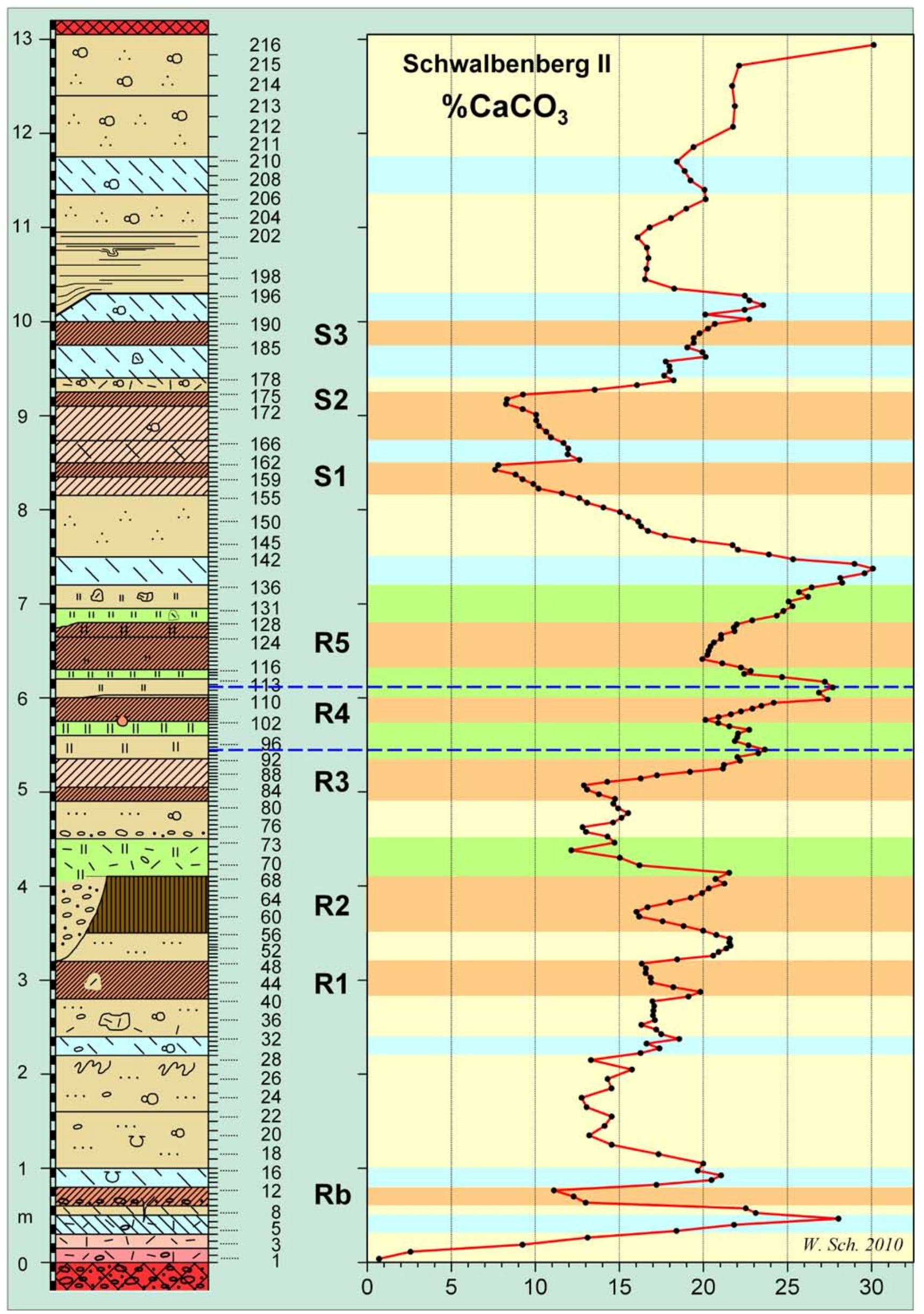

Fig. 7: Schwalbenberg II section with curve of the carbonate content. Profile legend see Fig. 2. Abb. 7: Profil Schwalbenberg II mit Karbonat-Kurve. Profillegende in Abb. 2. 
Ahrgau loess and Late Weichselian loess (Hesbaye and Brabant loess), the Keldach loess (samples no. 4-39) has the lowest average carbonate content (16.9\%), the Upper Pleniglacial loess (samples no. 197-215) the highest (18.9\%). The Ahrgau loess (samples no. 40-196) with its strongly varying carbonate curve has an average carbonate content of $18.8 \%$. The lower values of the Keldach loess (Lower Pleniglacial loess) in comparison to the higher values of the Upper Pleniglacial loess is a widespread phenomenon in central Europe: see for example measurements of the Middle Rhine (Boenigk et al. 1994), Upper Rhine (Bibus et al. 2007: 238) and Bavaria (BRUNNACKER 1957).

\section{Results and discussion}

The Schwalbenberg II section is tripartite into the Weichselian Lower Pleniglacial Keldach Formation, the Middle Pleniglacial Ahrgau Formation and the Upper Pleniglacial Hesbaye and Brabant Formations.

\subsection{Keldach Formation}

It starts with a strong unconformity, the wide-spread Keldach Discordance, cutting and reworking a great deal of the Rheingau Formation below. Reworked soil material is present from profile meter 0-0.5 (samples 1-7). Analytically this is reflected by sand input (Fig. 4-5) and augmentation of organic carbon (Fig. 6). Additional input of fresh loess material is indicated by silt (Fig. 4) and carbonate increase (Fig. 7). This solifluction layer at the base of the Keldach Formation is well known from central Europe and supplied with local names as „Basisfließerde“ (BRUNNACKER 1954) (i. e. basal solifluidal loam), „Niedervellmar-Bodenkomplex“ (Rohdenburg \& Meyer 1966) and as „Niedereschbach-Zone“ (SEMmel 1968).

The lower Keldach Formation is characterized by the interstadial brown Reisberg Soil. It has been formed on a solifluidal layer (sand increase in Fig. 4). The soil turns out to be autochthonous owing to a Corg peak (Fig. 4) and carbonate minimum (Fig. 7) in its very top.

In the most complete stratigraphy of the Keldach Formation on the Lower Rhine there occur two terrestric soils, the Jackerath Soil (regosol-cambisol) and the Spenrath Soil (regosol) (Schirmer 2002a: 19). One of them should match with the Reisberg Soil of the Schwalbenberg section. Both soils might correlate with the Greenland Interstadials 19 and 20 (Fig. 7). These weak terrestric soils are marker horizons for the lower part of the Keldach Formation.

Further criteria for the Keldach Formation in the Schwalbenberg section are prevalence of solifluidal loess with silt clods and crotovinas (Fig. 2), typical features for this formation in whole central Europe. Further characteristics are coarse silt prevalence of the grain size curve (Fig. 5), low values of the organic carbon curve (Fig. 6) and carbonate curve (Fig. 7). As typical marker horizons within the Keldach Formation, Grey Gelic Gleysols occur (SchIRMER 2002a: 19).

Whereas all these criteria of the Keldach Formation are typical for the Lower Pleniglacial (MIS 4) in central Europe, the TL and IRSL dates for the Keldach Formation show ages between 55-45 ka (Frechen \& Schirmer 2011) that do not match to MIS 4. Rather they would match to MIS 3.
From litho-pedological aspect it would be paradoxical to add this soil-poor loess section to the typical soil-rich Ahrgau Formation (MIS 3). The common separation of MIS 4 and MIS 3 is based on the delimitation of the cooler MIS 4 and the striking cluster of warmer and cooler spikes of MIS 3. In the terrestric environment this is realized by MIS 4 loess against the cluster of brown soils in MIS 3. Thus, from litho-pedological view the mentioned TL/IRSL data of this part are too young. Hints for a tendency being too young give already the numerical ages in the top of the Ahrgau Formation (MIS 3). In the Sinzig 3 soil ${ }^{14} \mathrm{C}$ ages of $32.7 \pm 0.4$ ka calBP (Fig. 2) contrast with an IRSL/REGEN age of 24.6 \pm 2.2 (Frechen \& Schirmer 2011, Fig. 5). In the top of the Keldach Formation the IRSL/REGEN age no. 11 of $44.9 \pm 3.7 \mathrm{ka}$ was fading-corrected to $53.9 \pm 4.7 \mathrm{ka}$ (FrEchen $\mho$ Schirmer 2011, Fig. 5). The upper value of this age range, $53.9+4.7$, would match excellently with the Upper boundary of MIS 4 of $58 \mathrm{ka}$ calBP. It shows up: There is latitude enough to move these IRSL dates.

\subsection{Ahrgau Formation}

The Ahrgau Formation contains eight fossil interstadial soils, seven cambisols and one regosol. It stands to reason that the top of all fossil soils is more or less truncated - as it is generally valid for nearly all fossil soils.

\section{Autochthony of the soils}

The Corg maximum of the single interstadial soils occurs towards the top of the soils in case of the Remagen 1 (R1), R 4, R5, Sinzig 1 (S1), S2 and S3 Soils (blue dashed lines in Fig. 6). It designates these soils as autochthonous soils with soil formation from their top downwards. Only in the case of the Remagen 2 and 3 Soils the Corg maximum appears in the midst of the soils. This may be due to a ongoing soil formation process accompanied by weak sedimentation after the peak of the soil formation with quiescence of sedimentation. In case of R3 this interpretation is visible in the profile by a weakening of the soil characters in the upper part of the soil. Consequently, all peaks with maxima at the top or in the midst of the soils show that the soils represent autochthonous soils and not reworked soil material. As the multiplicity of cambisols within the Ahrgau Formation of Schwalbenberg II contrasts to other loess sections in central Europe, the question arose whether some soils could be reworked soil material. In the case of reworked soil material the Corg peaks would not appear thus well developed and should occur in all positions of the visible soil material especially close to the base of the soil bands.

Another indicator for autochthony of the soils is the decalcification minimum at the soil top of the Remagen 1 Soil, Sinzig 1 and 2 Soils (Fig. 7; see discussion in chapter 4.3).

\section{Age of the soils}

The MIS 3 age of the Ahrgau Formation is assured by numerical datings: AMS ${ }^{14} \mathrm{C}$ ages from loess gastropods, TL and IRSL data from all horizons (Frechen \& SCHIRMER 2011) though they are somewhat too young (see above in chapter 5.1). However, even more convincing is the phenological comparison of the litho-pedological profile and the Corg curve of the Schwalbenberg II section with Green- 
land ice cores (Fig. 8) or deep-sea cores (SCHIRMER 2000a,b).

In Fig. 8 the organic carbon curve is compared with the $\delta^{18} \mathrm{O}$ record of the annual-layer counted Greenland GISP 2 core. The $\delta^{18} \mathrm{O}$ curve is arranged along the core depth and not along the time scale. It shows that in both, the loess section and the ice core, the sediment thickness per time is increasing upward.

The striking facts of matching with the Greenland ice cores and deep sea cores are the four Bond cycles represented by the soils R1, R2, R3-5, S1-3. In addition, in both records the Schwalbenberg and the Greenland ice cores, the widest cold gap (Kripp Stadial) lies between the third and the forth cycle. This gap is wider than the gaps between the individual peaks within the sequences. Initially, this gap was the reason for separating the Remagen Soil group from the Sinzig Soil group. A further conspicuous parallelism are the upward descending maxima spikes of the asymmetrically saw-tooth shaped peak lines of the Upper Remagen Soils (R3-5) resp. GIS 12-10, and that of the Sinzig Soils (S13) resp. GIS 8-6 (Fig. 7). These upward descending forms rapid warming and long cooling - were first described by Bond et al. (1993). Consequently, R1 corresponds to the GIS group 17-16, R2 to GIS 15-14, R 3 to GIS 12, R4 to GIS 11, R5 to GIS 10, S1 to GIS 8, S2 to GIS 7, S3 to GIS 6.

Moreover, Fig. 8 shows, that the highest peaks of the two curves, the Corg curve of the Schwalbenberg and the $\delta^{18} \mathrm{O}$ curve of the GISP 2, occur in both corresponding spikes: R2 respectively GIS 14, and R3 respectively GIS 12 .

Thus, shape and internal structure of the Corg curve of the Ahrgau Formation at Schwalbenberg is nearly the same than that in ice cores and marine cores. So much phenologic agreement of the Corg curve and the GISP 2 curve, together with the chronological data, leaves nearly no doubt that this loess section matches to MIS 3.

Above the Sinzig Soils there is a further Corg peak at sample 197 (Fig. 6). It is the base of a colluvial loess layer with sharp bedding planes. The colluvial loess might have reworked any soil from the Ahr Solcomplex in the hinterland. But it is also conceivable that it had reworked a theoretical Sinzig 4 Soil (S4). Looking at the Greenland interstadial group $8-5$ in Fig. 8 there are 4 interstadials, the peaks of which form an upward descending range. The same picture is given in the Corg curve of the Schwalbenberg. Yet, this is a mere phenomenon and discussed below in item 5.3.

\subsection{The boundary Ahrgau Formation/Hesbaye Formation}

In all terrestrial investigations on the Last Glacial the upper limit of the warmer middle part of the Last Glacial (MIS 3), characterized by a cluster of interstadial soils or deposits, is drawn with the top-line of the uppermost interstadial soil or deposit. Consequently, the first (loess) bed above this interstadial soil or layer represents the beginning of the Upper Pleniglacial period (MIS 2).

Accordingly, in all former papers concerning the Schwalbenberg section, I drew the upper limit of the Ahrgau Formation at the top-line of the youngest brown soil, which is the Sinzig 3 Soil. In the Schwalbenberg section this soil is overlain by a $30 \mathrm{~cm}$ thick weak Grey Gelic Gleysol, which again is unconformably cut off towards the Rhine valley by a laminated colluvial silt. The unconformable cut-off is the Hesbaye Discordance (see Fig. 2) that widely occurs at the base of the Hesbaye Formation (SCHIRMER 2003: 49) respectively at the base of the Upper Pleniglacial loess (RoHDENBURG 1968). This discordance can produce very deep erosion, sometimes down to the Rocourt Solcomplex (MIS 5) (Semmel 1968: 42) or deeper (Semmel \& StÄBleiN 1971: 26).

Thus, the Schwalbenberg section offers the possibility to draw the boundary Ahrgau/Hesbaye Formation with the Hesbaye Discordance, thus $30 \mathrm{~cm}$ higher than the first version. This higher situated boundary is favored by the following facts:

- In ice and deep sea curves the Bond cycle GIS 8-6 consists of four warm peaks. However, in the Schwalbenberg section only three warm peaks are present. Thus, the question arises whether the Schwalbenberg equivalent for GIS 5, the fourth warm peak, was eroded by the Hesbaye Discordance (Fig. 2). In case of its erosion, the Grey Gelic Gleysol above the Sinzig 3 Soil would belong to the Ahrgau Formation, and the following Hesbaye Discordance would indicate the beginning of the Hesbaye Formation.

- Hints for this version are given by the lithological data of the $30 \mathrm{~cm}$ Grey Gelic Gleysol above the Sinzig 3 Soil. This layer tends to fit more to the Ahrgau loess than to the Hesbaye loess: The grain sizes of fine silt, coarse silt and fine sand and the Corg values continue the trend of the Ahrgau loess. The lithologic break to the Hesbaye loess starts with the Hesbaye Discordance: lower values of Corg (Fig. 6), lower values of fine silt and fine sand, and higher values of coarse silt (Fig. 5).

- Moreover, there is a Corg peak at the very base of the colluvial loess overlaying the Hesbaye Discordance (Fig. 6). This peak may represent reworked Corg content of the Sinzig 4 Soil. The possible erosion of a Sinzig 4 Soil is shown in Fig. 9. However, likewise this peak may represent the Corg content of any soil that was eroded uphill by the reworking phase.

- However, there is a certain probability for the age of the Sinzig 3 Soil (S3) to match with the GIS 6 Interstadial: The AMS ${ }^{14} \mathrm{C}$ age of the S3, $28.200+300 /-290$ (see item 3.2), may be corrected after NotCal04 (VAN DER PLICHT et al. 2004) to around 33-33.5 ka calBP, or 32,3-33 a calBP CalPal corresponding to GIS 6 in the GISP2 core (Grootes \& STUIVER 1997).

- Moreover, the comparison with the well-dated northeastern Carpathian loess sections of Molodova (Ukraine) and Mitoc-Malu Galben (Romania) as well with the Siberian locality Kurtak (HAEsAerTs 2003, 2009) shows that the interstadial soils referring to GIS 6 have uncalibrated ${ }^{14} \mathrm{C}$ ages gained mostly from charcoal of about $28.5 \mathrm{ka} \mathrm{BP}$ - well fitting to the Sinzig 3 age. In contrast, the ${ }^{14} \mathrm{C}$ ages of soils referring to GIS 5 are $27.5-27.7 \mathrm{ka} \mathrm{BP}$, distinctly younger than the Sinzig 3 age of Schwalbenberg II. The ${ }^{14} \mathrm{C}$ ages of soils referring to GIS 7 have ages of 30-30.4 ka BP, evidently older than the Sinzig 3 age, rather fitting to the Sinzig 2 age of $28.860+300 /-290 \mathrm{ka} \mathrm{BP}$.

The closest loess equivalent with good subdivision of the MIS 3/MIS 2 transition is the Nussloch section on the Upper Rhine (BiBus et al. 2007, Antoine et al. 2009). The uppermost brown soil in the profiles of ANTOINE et al. (2009) is indicated as Lohne Soil, after its datings correlating to 


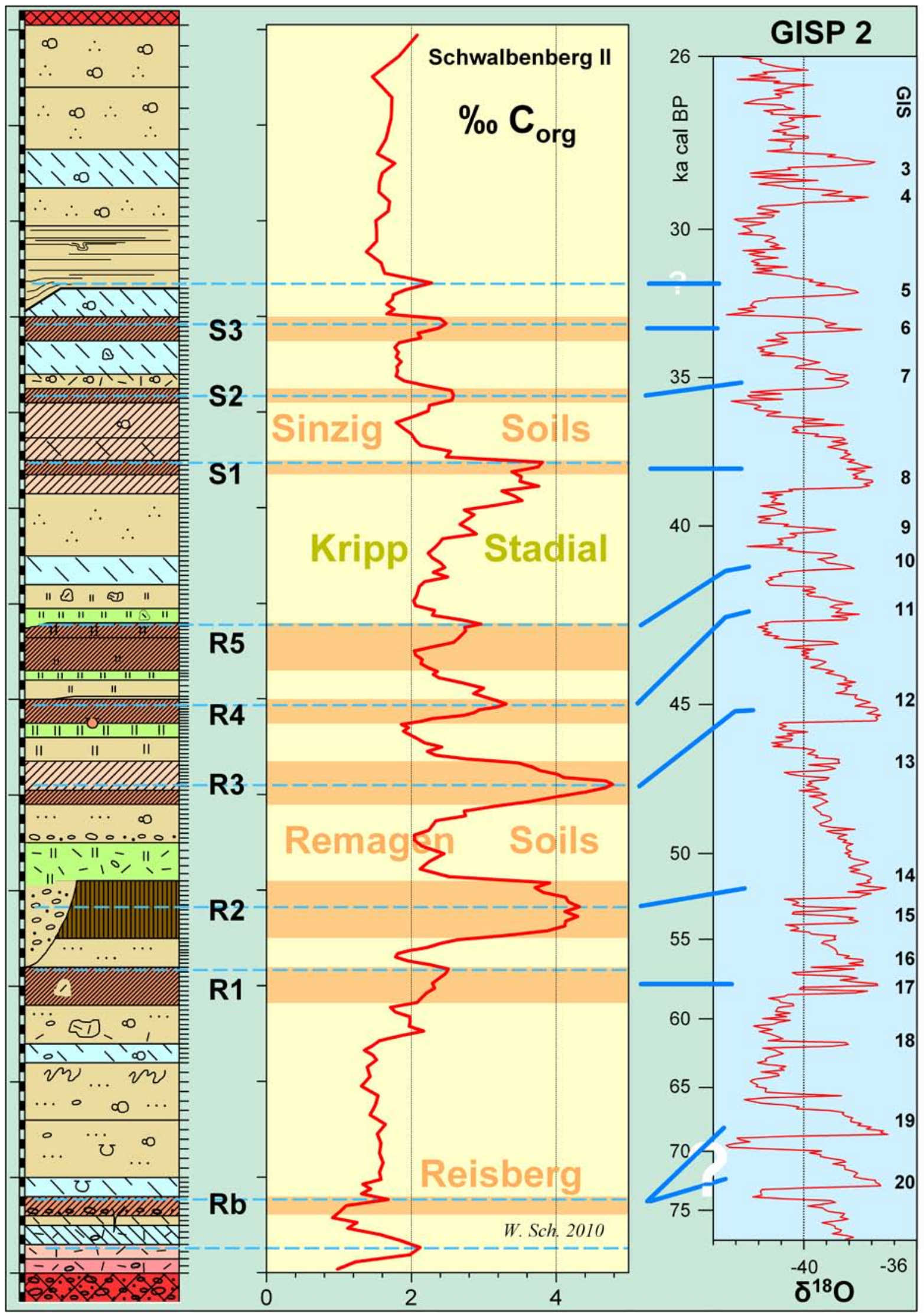

Fig. 8: Schwalbenberg II section and mean organic carbon curve of Schwalbenberg II, compared with the $\delta^{18} O$ curve of the Greenland ice core GISP 2 (GROOTES \& STUIVER 1997). In the GISP 2 diagram the vertical scale (not drawn) is the ice core depth from meter 1997 down to 2640. Added is the non-linear time scale. Legend for the litho-pedo column see Fig. 2. GIS = Greenland Interstadial, $R b=$ Reisberg Soil, $R=R e-$ magen Soil, $S=$ Sinzig Soil. Profile legend see Fig. 2.

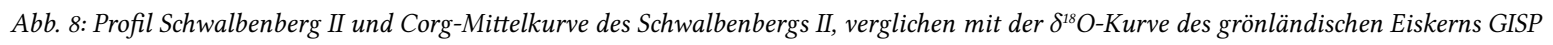
2 (GROOTES \& STUIVER 1997). Die Vertikalskala im GISP 2-Diagramm fußt auf der Eiskerntiefe von Meter 1997 bis 2640 (nicht beschriftet); beschriftet ist die nicht-lineare Zeitskala. Legende der Litho-pedo-Säule in Abb. 2. GIS = Grönland-Interstadial, Rb = Reisberg-Boden, $R=$ Remagen-Boden, $S=$ Sinzig-Boden. Profillegende in Abb. 2. 


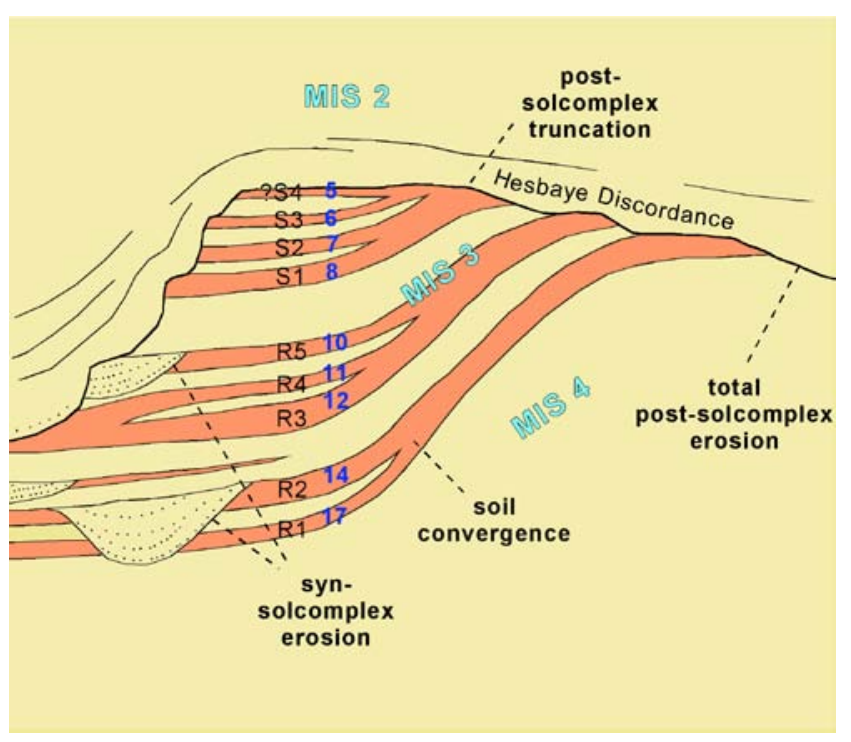

Fig. 9: Scheme of diminution of the Ahr interstadial solcomplex (MIS 3) by convergence, syn-solcomplex erosion and post-solcomplex erosion of soils. The scheme shows the solcomplex sandwiched between the Keldach Formation and the Hesbaye Formation. HD = Hesbaye Discordance, MIS = Marine Isotope Stage, R1-R5 = Remagen Soils, S1-S4 = Sinzig Soils, blue numbers 5-17 = affiliation to Greenland Interstadials 5-17. The loesses of the Keldach Formation (MIS 4) below and the Hesbaye Formation (MIS 2) on top of the Ahrgau Formation (MIS 3) are not shown differentiatedly (modified after SCHIRMER 2010: 34).

Abb. 9: Schema der Verminderung des Ahr-Interstadial-Solkomplexes (MIS 3) durch Konvergenz, Syn-Solkomplex-Erosion und Post-SolkomplexErosion von Böden. Das Schema zeigt den Solkomplex zwischen der Keldach- (MIS 4) und Hesbaye-Formation (MIS 2) gelegen, die in sich nicht mehr weiter untergliedert dargestellt sind. HD = Hesbaye Diskordanz, MIS = Marines Isotopen-Stadium, R1-R5 = Remagen Böden, S1-S4 = SinzigBöden, blaue Zahlen 5-17 = Verknüpfung mit den Grönland-Interstadialen 5-17 (verändert nach SCHIRMER 2010: 34).

GIS 7. Thus, it would correspond to S2 of the Schwalbenberg. Above it in Nussloch Antoine et al. (2009) only note gelic gleysols.

Consequently, the Sinzig 3 Soil should represent the warm phase of GIS 6. In this case the Hesbaye Discordance has cut the top part of the Ahrgau Formation. The $30 \mathrm{~cm}$ thick Grey Gelic Gleysol is constituent of the Ahrgau Formation and the expected Sinzig 4 Soil may be appear in the reworked Corg peak at the base of the Hesbaye loess represented by the colluvial silt layer.

\subsection{Hesbaye and Brabant Formations}

The Hesbaye Formations starts with the Hesbaye Discordance. Within the $3 \mathrm{~m}$ thick loess between the Hesbaye Discordance and the surface there is only one Grey Gelic Gleysol developed. The Hesbaye Formation normally hosts up to three Grey Gelic Gleysols, the Erbenheim 1-3 Soils (SchönhALs et al. 1964). Owing to the incomplete development of the Upper Pleniglacial section neither it is possible to assign this gleysol to a distinct one of the Erbenheim Soils nor it is known whether the uppermost loess contains shares of the Brabant Formation. Sand augmentation in the uppermost part of the section (samples 214-216, Fig. 3) is due to eolian sand accompanying the silt of the loess.

Up to now in the descriptions of the Hesbaye Formation nowhere in central Europe a hint of a brown or humus soil is given that could represent an equivalent of the warming peaks GIS 3 and 4 around 28-29 ka cal BP.

\section{Conclusion}

A terrestrial equivalent of the marine and inland ice MIS 3 was exposed at the Schwalbenberg on the left slope of the River Rhine close to Remagen. The stadial phases are represented by loess layers, interstadial phases by eight fossil terrestric soils, seven cambisols and one regosol. Compared with ice cores - in this paper the $\delta^{18} \mathrm{O}$ curve of the annual-layer counted GISP 2 core - and deep sea cores it turns out that the Schwalbenberg section shows the Ahrgau Formation (MIS 3) in its most complete preservation in western central Europe. A striking phenomenon remains that this formation in most loess sections of central Europe appears more or less reduced, sometimes reduced down to one cambisol only. A possible answer for this phenomenon is given in SCHIRMER (2010: 38): The diminution of soils within the Ahr Solcomplex occurs by convergence of soils, due to thinning of loess deposition between soil formation (Fig. 9), by erosional activity of soils during the cold phases between the interstadials (syn-solcomplex truncation) and also by erosional activity after completion of the Ahr Solcomplex (post-solcomplex truncation of parts or the whole solcomplex).

Thus, elsewhere in central Europe there are three soils, two soils or even only one soil preserved. In cases of one preserved soil it remains questionable which soil of the eight-membered solcomplex has been preserved at the place described, and whether this one soil is always the same soil among the variety of members of the whole solcomplex.

The strongest interstadials of the Schwalbenberg section are Remagen 1, Remagen 2 and Remagen 3 concerning the clay formation (Fig. 5). Concerning the amount of Corg, Remagen 2, Remagen 3 and Sinzig 1 are dominant (Fig. 8). The warmest interstadials in the ice cores (Fig. 8) are GIS 17+16 (corresponding to Remagen 1), GIS 14 (corresponding to Remagen 2), GIS 12 (corresponding to Remagen 3) and GIS 8 (corresponding to Sinzig 1) - even here appears conformity between Schwalbenberg and ice core. Consequently, the warmer part of MIS 3 is not the uppermost part, rather the lower section. Therefore, regarding the probability of preservation of the fossil soils from erosion this lower section is favored.

As shown in this paper it turns out that even the soilrich Schwalbenberg section is not complete. The equivalent of the GIS 5 interstadial seems to be eroded by the Hesbaye Discordance - the case of post-solcomplex truncation (as shown in Fig. 9). On the other hand, there exist sections of the Ahrgau Formation presenting a more detailed stratigraphy than that of the Schwalbenberg, for example the sections Molodova (Ukraine) and Mitoc-Malu Galben (Romania) as well as the Siberian locality Kurtak (HAESAERTs et al. 2003, 2009). Thus, the more continental areas of Eurasia seem to be less affected by erosional processes causing synsolcomplex or post-solcomplex mutilations. Regarding the Schwalbenberg in this light, its plentiful configuration of members seems to be a happy coincidence for the western part of central Europe. 
Tab. 1: Profile log Schwalbenberg II.

Tab. 1: Profilbeschreibung Schwalbenberg II.

The pedologic abbreviations follow the German pedological soil labeling (AG Boden 2005). In addition, letter M is used for reworked soils or soil sediment, letter $N$ stands for Nassboden (gelic gleysol), $N^{‘}$ means weak gelic gleysol and $N^{\prime \prime}$ means very weak gelic gleysol. The number behind a soil horizon gives its thickness in cm. Following numbers in brackets are the soil samples (see Fig. 2).

Surface

BtM up to 1.5 m Bt horizon, slightly reworked: Loam, silty, reddish brown, non-carbonaceous

Ckc 65 cm [samples 216-214] Loess: Loam, silty, light yellow-brown, carbonaceous, numerous loess dolls

Ckc 65 [213-211] Loess: Loam, silty, light grey-yellow, carbonaceous, copious loess dolls

CkcfNr” 40 [210-207] Weak Grey Gelic Gleysol: Loam, silty, light grey-yellow, slightly grey streaked, very weak rusty streaks, carbonaceous, loess dolls Ckc 40 [206-203] Loess: Loam, silty, light grey-yellow, carbonaceous, loess dolls

C 65 [202-197] Colluvial loess: Loam, silty, light brown-yellow and light grey-yellow banded, carbonaceous, small cryoturbations; towards east downcutting into the underlying gelic gleysol

Erosional discordance

fNr' 30 [196-191] Weak Grey Gelic Gleysol: Loam, silty, light brown-grey, very few rusty speckles, carbonaceous, little carbonate pseudo-mycelia, few small loess dolls, small Fe-Mn-concretions

fBcv 25 [190-186] Weak calcic cambisol [Sinzig 3 Soil]: Loam, silty, brown, carbonaceous, carbonate pseudo-mycelia, worm dike internal casts $[-4 \mathrm{~mm} ø]$, Fe-Mn-coated root tracks, coherent structure, burrows up to $1 \mathrm{~cm} ø$ and $15 \mathrm{~cm}$ depth

fNr 35 [185-179] Weak Grey Gelic Gleysol: Loam, silty, light brown-grey, carbonaceous, some loess dolls, very few carbonate pseudo-mycelia, worm dike casts [ $-4 \mathrm{~mm} \emptyset]$, Fe-Mn-coated root tracks, some clods of reworked brown soil material up to $10 \mathrm{~cm} \emptyset$

$\mathrm{Nr}+\mathrm{BM} 15$ [178-176] Weak Grey Gelic Gleysol: Loam, silty, light brown-grey, carbonaceous, some loess dolls, very few carbonate pseudo-mycelia worm dike casts $[-4 \mathrm{~mm} ø]$, Fe-Mn-coated root tracks, rich in reworked brown soil material of the underlying bed, loess doll layer at the top

fBcv1 15 [175-173] Calcic cambisol [Sinzig 2 Soil]: Loam, silty, slightly clayey, brown, carbonaceous, few carbonate pseudo-mycelia, some loess dolls, worm dike internal casts [2-4 mm ø], small Fe-Mn-coated root tracks

Bcv2 35 [172-167] Loam, silty light brown, carbonaceous, few carbonate pseudo-mycelia, some loess dolls [-2 cm ø], small Fe-Mn-coated root tracks

fNrBcv2 25 [166-163] Loam, silty, light brown-grey, grey spots up to $5 \mathrm{~cm} \emptyset$, carbonaceous, few carbonate pseudo-mycelia, some loess dolls $[-2 \mathrm{~cm} \emptyset]$, small Fe-Mn-coated root tracks

fBcv1 15 [162-160] Calcic cambisol [Sinzig 1 Soil]: Loam, silty, brown, carbonaceous, carbonate pseudo-mycelia, Fe-Mn-coated root tracks

Bcv2 20 [159-156] Loam, silty, light brown, carbonaceous, carbonate pseudo-mycelia, Fe-Mn-coated root tracks

C 65 [155-143] Loess: Loam, silty, light yellow-brown, carbonaceous, carbonate pseudo-mycelia

fNr' 30 [142-137] Weak Grey Gelic Gleysol: Loam, silty, light brown-grey, carbonaceous, carbonate pseudo-mycelia

fNg' 25 [136-132] Weak Speckled Gelic Gleysol: Loam, silty, light grey-brown, very weak grey and rusty speckles, carbonaceous, carbonate pseudomycelia, brownish clods of solifluidal loess up to $10 \mathrm{~cm} ø$

$\mathrm{Ng} 15$ [131-129] Speckled Gelic Gleysol: Loam, silty, light brown-grey, strong grey and rusty speckles, in the lowest 5 cm the lightest speckles, carbonaceous, carbonate pseudo-mycelia, large brown clods of solifluidal loess reworked from the underlying soil; base line unconformably downcutting into the underlying soil

Erosional discordance

fSdBcv 15 [128-125] Calcic cambisol [Remagen 5 Soil]: Loam, silty, very weakly gravelly [ $-1,5$ cm ø], brown, bleached vertical streaks bounded by rust seams, carbonaceous, carbonate pseudo-mycelia, vertical worm dykes with humic brown infill up to $1 \mathrm{~mm} \emptyset$

Bcv 35 [124-117] Loam, silty, brown, very few, weak, grey, rust-bounded speckles [1-3 cm ø], carbonaceous, carbonate pseudo-mycelia, vertical worm dykes with humic brown infill up to $1 \mathrm{~mm} \emptyset$

fNg' 10 [116-114] Weak Speckled Gelic Gleysol: Loam, silty, very weakly fine-gravelly, light grey-brown, little rusty and strongly grey speckled, carbonaceous, carbonate pseudo-mycelia, vertical worm dykes with humic brown infill up to $1 \mathrm{~mm} \emptyset$

Ng" 17 [113-111] Loam, silty, light grey-brown, very weakly rusty and grey speckled, carbonaceous, carbonate pseudo-mycelia, vertical worm dykes with humic brown infill up to $1 \mathrm{~mm} \emptyset$

C 3 Colluvial layer: Loam, fine sandy, and Loam, silty, light yellow-brown, mm-thin bedding, carbonaceous

fBcv 25 [110-103] Calcic cambisol [Remagen 4 Soil]: Loam, silty, brown, sporadic gravel lines [up to 2 cm ø], carbonaceous, carbonate pseudomycelia; vertical burrows, very weakly carbonaceous, baggy deepened into the underlying bed

fNg 15 [102-99] Speckled Gelic Gleysol: Loam, silty, very weakly fine-gravelly”, light grey-brown, strong grey and rusty speckling, carbonaceous, carbonate pseudo-mycelia 
$\mathrm{Ng}^{\prime} 25$ [98-93] Loam, silty, light grey-brown, weakly grey and rusty speckled, carbonaceous, carbonate pseudo-mycelia

fBcv 30 [92-85] Calcic cambisol [Remagen 3 Soil]: Loam, silty, very weakly medium-gravelly, yellow brown, somewhat lighter than the horizon below, carbonaceous, carbonate pseudo-mycelia

Bcv 15 [84-82] Loam, silty, slightly clayey, very weakly fine-gravelly, yellow brown, carbonaceous, carbonate pseudo-mycelia, Fe-Mn-concretions

C 35 [81-75] Solifluidal loess: Loam, silty, weakly fine-gravelly, light yellow-brown, carbonaceous, carbonate pseudo-mycelia, very few loess dolls, Fe-Mn-concretions

C 5 [74] Gravel layer: Loam, fine-gravelly, medium to coarse sandy, light yellow-brown, carbonaceous

MfNg 40 [73-69] Speckled Gelic Gleysol on solifluidal loess: Loam, silty, weakly fine sandy, strongly fine gravelly, light yellow-brown, rusty and grey speckled, reddish brown reworked streaks and shreds of soil sediment, carbonaceous, carbonate pseudo-mycelia, Fe-Mn-concretions

C 0-80 Local channel filled with gravel: Fine to medium gravel, fine to medium sandy, silty, carbonaceous

Erosional discordance

fAh 60 [68-57] Calcic regosol [Remagen 2 Soil]: Loam, silty, slightly clayey, very weakly gravelly, grey brown, weakly humic, carbonaceous, many Fe-Mn-concretions

C 30 [56-49] Solifluidal loess: Loam, silty, very weakly gravelly, light grey-brown, carbonaceous

fBcv 40 [48-41] Calcic cambisol [Remagen 1 Soil]: Loam, silty, slightly clayey, very weakly fine-gravelly, brown, carbonaceous, light brownish grey clods of loam $[-25 \mathrm{~cm} \emptyset]$

Ckc 40 [40-33] Light brown solifluidal loess: Loam, silty, very weakly fine-gravelly, light brown, brown and grey clods of solifluidal loam of 0,5-2 $\mathrm{m}$ ø, mm-thin light silt shreds, carbonaceous, few loess dolls

fNr" २० [32-29] Very weak Grey Gelic Gleysol: Loam, silty, very weakly fine-gravelly, light brownish grey, scattered light irregular spots without traces of rust, $\mathrm{mm}$-thin light silt shreds, carbonaceous, few loess dolls

Ckc 60 [28-23] Light brown solifluidal loess: Loam, silty, fine sandy, very weakly gravelly, light brown, carbonaceous, carbonate pseudo-mycelia, loess dolls up to $2 \mathrm{~cm} \emptyset$, many Mn-concretions and -streaks; in the upper part strong solifluidal involutions

Ckc 60 [-40 cm] [22-17] Light yellow-brown solifluidal loess: Loam, silty, fine sandy, very weakly gravelly, light yellow-brown, [without Mn-spots], carbonaceous, few carbonate pseudo-mycelia, loess dolls

fCkcNr 20 [-40 cm] [16-13] Grey Gelic Gleysol: Loam, silty, fine sandy, very weakly fine-gravelly, light brown-grey, carbonaceous, very few loess dolls, $\mathrm{Mn}$-spots, in the basal part reworked material from the underneath layer, large crotovinas

fBM 20 [12-10] Brown solifluidal loam [Reisberg Soil]: Loam, silty, fine sandy, brown, copious Mn-spots, carbonaceous, frost cracks; locally a basal band of fine gravel up to $10 \mathrm{~cm}$ in thickness

fNr" 10 [9-8] Loess with weak Grey Gelic Gleysol: Loam, silty, fine sandy, light grey-brown, carbonaceous

Nr’ 20 [7-5] Solifluidal Grey Gelic Gleysol: Loam, silty, fine sandy, very weakly gravelly, light grey and light grey-brown scraps, very few rusty speckles, carbonaceous, sporadic clods of reddish brown loam

BtM 15 [4-3] Reddish solifluidal loam: Loam, fine sandy, silty, very weakly gravelly, light reddish brown, carbonaceous

BtM 15 cm [samples 2-1] Red solifluidal loam: Loam, fine sandy, silty, very weakly gravelly, reddish brown, with clods and scraps of a gelic gleysol, carbonaceous

Erosional discordance

Bt $180 \mathrm{~cm}$ Fluvial channel deposit: Medium to coarse gravel, block-bearing, top red brown, downward grey brown, copious streaks of skeleton gravel [grain-supported gravel], sand striae, little loam striae, cross-bedding, trough bedding, single pebbles with clay coating, high content of slate, decalcified, secondary slightly carbonaceous from above

Bv $500 \mathrm{~cm}$ Medium to coarse gravel, block-bearing, horizontal to slight trough bedding in layers of 1-2 dm in thickness, gravel rich in matrix, medium-sandy, loamy, yellow brown, interbedded with brown skeleton gravel, poorer in slate than the gravel above it, $2 \mathrm{~m}$ below the upper bound a drift boulder of $80 \times 50 \mathrm{~cm}$ of milky quartz.

Underlying bed: not exposed. 


\section{Acknowledgements}

Thanks to Dr. Antje Voelker for providing me with ice core literature, and thanks to Prof. Dr. Manfred Frechen and a further reviewer for giving useful hints that improved the manuscript.

\section{References}

AG Boden (2005): Bodenkundliche Kartieranleitung. - 5. Aufl., 438 S. Hannover.

Antoine, P., Rousseau, D.-D., Moine, O., Kunesch, S., Hatté, C., Lang A., Tissout, H \& Zöller, L. (2009): Rapid and cyclic aeolian deposition during the Last Glacial in European loess: a high-resolution record from Nussloch, Germany. - Quaternary Science Reviews, 28 (25-26): 2955-2973.

App, V., Auffermann, B., Hahn, J., Pasda, C. \& Stephan, E. (1995), mit Beiträgen von BaAles, M., Bibus, E. RÄhle, W., Rottländer, R., Schoch, W. \& Steppan, K.-H.: Die altsteinzeitliche Fundstelle auf dem Schwalbenberg bei Remagen. - Trierer Zeitschrift, Beiheft 20: 11-136, Beil. 1-2; Trier.

Bibus, E., Frechen, M., Kösel, M. \& RÄhle, W. (2007): Das jungpleistozäne Lössprofil von Nussloch (SW-Wand) im Aufschluss der Heidelberger Zement AG. - E\&G Quaternary Science Journal, 56 (4) 227-255.

Boenigk, W., Frechen, M. \& Weidenfeller, M. (1994): Die mittel- und oberpleistozäne Deckschichtenfolge im Naturschutzgebiet „Eiszeitliches Lößprofil” in Koblenz-Metternich. - Mainzer geowissenschaftliche Mitteilungen, 23: 287-320.

Bond, G., Broecker, W., Johnsen, S., McManus, J., Labayrie, L., Jouzel J. \& BonANI, G. (1993): Correlations between climate records from North Atlantic sediments and Greenland ice. - Nature, 365: 143-147.

BRUNNACKer, K. (1954): Löß und diluviale Bodenbildungen in Südbayern. Eiszeitalter und Gegenwart, 4/5: 83-86.

BRUNNACKeR, K. (1957): Bemerkungen zur Feinstgliederung und zum Kalkgehalt des Lösses. - Eiszeitalter und Gegenwart, 8: 107-115.

COFFLET, L. (2005): Paläomagnetische Untersuchungen im rheinischen Löss - Inaugural-Dissertation Universität Düsseldorf (Abteilung Geologie): $152 \mathrm{~S}$.

Frechen, M. \& Schirmer, W. (2011): Luminescence Chronology of the Schwalbenberg Loess in the Middle Rhine Valley. - E\&G Quaternary Science Journal, 60 (1): 78-89.

Grootes, P. M. \& Stuiver, M. (1997): Oxygen 18/16 variability in Greenland snow and ice with 10-3 to 105-year time resolution. - Journal of Geophysical Research, 102 (C12): 26,455-26,470.

Haesaerts, P., Borziac. I., Chekha, V.P., Chirica, V., Damblon, F., Drozdov, N. I., Orlova, L. A., Pirson, S. \& van der Plicht, J. (2009): Climatic signature and radiocarbon chronology of middle and late Pleniglacial loess from Eurasia: Comparison with the marine and Greenland records. - Radiocarbon, 51, (1): 301-318.

Haesaerts, P., Borziac, I., Chirica, V., Damblon, F., Koulakovska, L. ひ VAN DER Plicht, J. (2003): The East Carpathian loess record: a reference for the middle and late pleniglacial stratigraphy in central Europe. - Quaternaire, 14 (3): 163-88.

Rohdenburg, H. (1968): Jungpleistozäne Hangformung in Mitteleuropa - Beiträge zur Kenntnis, Deutung und Bedeutung ihrer räumlichen und zeitlichen Differenzierung. - Göttinger Bodenkundliche Berichte, 6: 3-107.

Rohdenburg, H. \& Meyer, B. (1966): Zur Feinstratigraphie und Paläopedologie des Jungpleistozäns nach Untersuchungen an südniedersächsischen und nordhessischen Lößprofilen. - Mitteilungen der Deutschen Bodenkundlichen Gesellschaft, 5: 1-137.
Schiermeyer, J. (2000): Würmzeitliche Lößmollusken aus der Eifel. - Inaugural-Dissertation Universität Düsseldorf (Heinrich-Heine-Universität): $125 \mathrm{~S}$.

SCHIRMER, W. (1990a): Schwalbenberg südlich Remagen. - In: ScHIRMER, W. (ed.): Rheingeschichte zwischen Mosel und Maas. - deuqua-Führer 1: 94-98; Hannover (DEUQUA)

Schirmer, W. (1990b): Die Goldene Meile. - In: Schirmer, W. (Hrsg.) Rheingeschichte zwischen Mosel und Maas. - deuqua-Führer, 1: 94-98; Hannover (DEUQUA).

Schirmer, W. (1991): Würmzeitliche Paläoböden am Mittelrhein. 10. Tagung des Arbeitskreises Paläoböden der Deutschen Bodenkundlichen Gesellschaft vom 30. 5. - 1. 6. 1991 in Bonn, Programm und Exkursionsführer: 70-83.

Schirmer, W. (1995a): The Oberrheingraben and its borders. - In: Schirmer, W. (ed.): Quaternary field trips in Central Europe, 1. - 511-520; München (Pfeil)

Schirmer, W. (1995b), Mittelrhein Basin and lower Mittelrhein. - In Schirmer, W. (ed.): Quaternary field trips in Central Europe, 1. 524-537; München (Pfeil).

Schirmer, W. (1999): Kaltzeiten und Warmzeiten im Löß. - In: BecKerHaumann, R. \& Frechen, M. (ed.): Terrestrische Quartärgeologie. 81-100; Köln (Logabook).

Schirmer, W. (2000a): Rhein loess, ice cores and deep-sea cores during MIS 2-5. - Zeitschrift der deutschen geologischen Gesellschaft, 151 (3): 309-332.

Schirmer, W. (2000b): Eine Klimakurve des Oberpleistozäns aus dem rheinischen Löss. - Eiszeitalter und Gegenwart, 50: 25-49.

Schirmer, W. (2002a): Compendium of the Rhein loess sequence. - In IKINGER, A. \& Schirmer, W. (eds.): Loess units and solcomplexes in the Niederrhein and Maas area. - Terra Nostra, 2002 (1): 8-23, 102-104.

Schirmer, W. (2002b): Frühes Würm/Weichsel im Rahmen der GlazialInterglazial-Gliederung. - Terra Nostra, 2002 (6): 314-321.

Schirmer, W. (2003): Stadien der Rheingeschichte. - In: Schirmer, W (ed.): Landschaftsgeschichte im Europäischen Rheinland. GeoArchaeoRhein, 4: 21-80.

Schirmer, W. (2004): Terrestrischer Klimagang des MIS 3. - In: DEUQUA meeting, 30. August-3. September 2004, Nijmegen, the Netherlands. Abstract volume: 74 .

Schirmer, W. (2010): Interglacial complex and solcomplex. - Central European Journal of Geosciences, 2 (1): 32-40.

Schönhals, E., Rohdenburg, H. \& Semmel, A. (1964): Ergebnisse neuerer Untersuchungen zur Würmlöß-Gliederung in Hessen. - Eiszeitalter und Gegenwart, 15: 199-206.

Semmel, A. (1968): Studien über den Verlauf jungpleistozäner Formung in Hessen. - Frankfurter geographische Hefte (?), 45: 133 S.; Frankfurt am Main.

Semmel, A. \& StÄBlein, G. (1971): Zur Entwicklung quartärer Hohlformen in Franken. - Eiszeitalter und Gegenwart, 22: 23-24.

Singer, B. S., Guillou, H., Jicha, B. R., LaJ, C., Kissel, C., Beard, B. L. \& Johnson, C. M. (2009): 40Ar/39Ar, K-Ar and 230 Th-238U dating of the Laschamp excursion: A radioisotopic tie-point for ice core and climate chronologies. - Earth and Planetary Science Letters, 286: 80-88.

VAn der Plicht J., Beck, J.W., Bard, E., Baillie, M.G.L, Blackwell, P.G., Buck, C.E., Friedrich, M., Guilderson, T.P., Hughen, K.A., Kromer, B., McCormac, F.G., Bronk Ramsey, C., Reimer, P.J., Reimer, R.W., Remmele, S., Richards, D.A., Southon, J.R., Stuiver, M. \& Weyhenmeyer, C.E. (2004): NotCal04 - comparison/calibration ${ }^{14} \mathrm{C}$ records $26-50$ cal kyr BP. - Radiocarbon, 46 (3): 1225-1238.

Werner, H. (1973): Ein vollautomatisches Pipettiergerät für die Korngrößenbestimmung nach Köhn. - Zeitschrift für Pflanzenernährung und Bodenkunde, 134 (1): 52-56.

Zöller, L., ConARd, N. J. \& Hahn, J. (1991): Thermoluminescence dating of middle Palaeolithic open air sites in the Middle Rhine Valley/Germany. - Naturwissenschaften, 78: 408-410. 